\title{
An ecological and comparative analysis of parasites in juvenile Mugil liza (Pisces, Mugilidae) from two sites in Samborombón bay, Argentina
}

\author{
Martin M. Montes \& Sergio R. Martorelli
}

Centro de Estudios Parasitológicos y Vectores (CEPAVE), Consejo Nacional de Investigaciones Científicas y Técnicas, Universidad Nacional de La Plata (CCT-La Plata-CONICET-UNLP), Calle 122 y 60 sin número, CP 1900, La Plata, Argentina

\begin{abstract}
Mugil liza Valenciennes, 1836 is an economically important food fish and has been recommended for aquaculture in South America. A total of 278 fishes were collected in the spring and summer of 2009 and 2010. These fish were sorted into sample groups according to their size class. We used Bayesian statistics and $95 \%$ credible intervals for each parameter tested were calculated. Fish studied harbored a total of 15 different species of parasites. Diversity of parasite species found on Mugil liza was greatest at the S.R.C. collection site, but evidenced a lower species richness than at A.R. site. The 1st size fishes of both sites evidenced greater parasite diversity than either 2nd or 3rd size fish. Differences observed could be explained by the different use of habitat types at the two sites or differential susceptibility to infection by parasites. The dominance of $D$. fastigata influenced observed results of lower community diversity indexes. New works elucidating different parasite life cycles within juvenile and adults of $M$. liza in Argentina, promise to be important for determining the risk of the parasitism by zoonotic metacercariae $A$. (P.) long $a$ and use of this fish as food and an economic resource, and the possible use of mullet parasites in other promising fields as indicators of biodiversity, and/ or water contamination.
\end{abstract}

KEYWORDS. Bayesian statistic, Ascocotyle, Dicrogaster, Hymenocotta, Phyllodistomum.

RESUMEN. Análisis ecológica y comparativa de parásitos en juveniles de Mugil liza (Pisces, Mugilidae) de dos sitios en la baía Samborombón, Argentina. Mugil liza, Valenciennes, 1836 es un pez de importancia comercial y ha sido recomendado en Sudamerica para la acuicultura. Los peces se distribuyeron en grupos de acuerdo con la talla. Usamos estadística Bayesiana e intervalos de credibilidad del $95 \%$ para cada parámetro calculado. Los peces alojaron un total de 15 especies parasitarias. La diversidad de las especies parasitas de M. liza fue mayor en el sitio de colecta S.R.C., pero evidencio una menor riqueza especifica que en A.R. La 1er talla de los peces de ambos sitios evidencio una mayor diversidad parasitaria que la 2da o 3er talla. Las diferencias observadas se pueden explicar por un uso diferente del hábitat en los dos sitios o a una susceptibilidad diferente a la infección por los parasitos. La influencia de la dominancia de $D$. fastigata resulta en el menor índice de diversidad de la comunidad. Nuevos trabajos que diluciden los diferentes ciclos de vida de los parásitos en los juveniles y adultos de $M$. liza en Argentina, prometen ser importantes para determinar el riesgo del parasitismo de la metacercaria zoonotica $A$. (P.) longa y el uso de este pez como alimento, una fuente económica y el posible uso de los parásitos de la lisa en otros promisorios campos como indicadores de biodiversidad y/o contaminación acuática.

PALABRAS CLAVE. Estadística Bayesiana, Ascocotyle, Dicrogaster, Hymenocotta, Phyllodistomum.

The Estuary of the Rio de la Plata is the second largest hydrologic basin of South America (URIEN, 1967; FrAMIÑAN \& BROWN, 1996) and the most important within Argentina. Samborombón Bay, found within the estuary of the Rio de la Plata, was declared a RAMSAR site since 1997 (Ramsar Convention Bureau, 2015). Within the Bay of Samborombón it is evident that a north-south gradient in the concentrations of the nutrients, phosphorus, nitrogen exists (SCHENONE et al., 2008) due to the northern lotic systems receiving nutrients from the high basin where extensive agricultural and livestock activity has developed (Fernandez Cirelli et al., 2006). In the south of the Bay the oceanic influence is higher than in the north for two reasons, first, the proximity of the Ajó River to the sea and the great distance from the discharge of fresh water from the Parana and Uruguay Rivers into La Plata River (SCHENONE et al., 2007, 2008).

Mugil liza Valenciennes, 1836, an economically important food fish has been recommended for aquaculture in South America (GodinHo et al., 1988; OIA, 2007), is the only mullet that breeds in Argentina (GonZALEZ CASTRO et al., 2011)
Many works have been published about lebranche mullet parasites (CHIEFFI, 1990; ChIEFFI et al., 1992; KNOFF \& Amato, 1992; Knoff \& Boeger, 1994; Knoff et al., 1994; Amado \& Rocha, 1995; Martinez OKumura et al., 1999; Scholz, 1999; Suriano et al., 2000; Fernandes \& Cohen, 2006; Aparecida de Oliveira et al., 2007; AbDallah et al., 2009; Failla Siquier \& OstrowsKi DE NuÑez, 2009; MARCotegui et al., 2009; MARCOTEGUI \& Martorelli, 2009; Simões et al., 2010; Montes et al., 2013), but ecological papers have focused mainly on adult fish (KNoff et al., 1997; Ranzani-Paiva \& Silva Souza, 2004; Alarcos \& Etchegoin, 2010), only Carnevia \& SPERANZA (2003) working with juvenile from Uruguay reported some population indices.

The main objective of this work is to compare the metazoan parasite populations and parasite communities, at the component and infracommunity levels, of juvenile lebranche mullet in two sites within Samborombón Bay and analyze the distribution of the zoonotic metacercariae of $A$. (P.) longa, recently reported by MARTORELLi et al. (2012), in juvenile mullet of different sizes. 


\section{MATERIAL AND METHODS}

The samples were collected in two sites of the Samborombón Bay, one in the north of the bay (Salado River relief Channel - S.R.C., 3550'10"S, 57 50'20”W) and other in the south (Ajó River - A.R., 36 20'12"S, $56^{\circ} 54^{\prime} 17^{\prime} \mathrm{W}$ ). Both localities were clearly defined and described by SCHENONE et al. $(2007,2008)$.

Juvenile lebranche mullet were sampled in the spring and summer of 2009 and 2010 and collected from the coastal region using cast-nets, and fixed nets. The mullet sampled were divided into study groups (Tab. I) following the sizes established by GonZALEZ CASTRO et al. (2011) and, as such, size corresponds to the age in the following manner; size 1 fish were (age 0-1 year), size 2 (age 2 yr) and size 3 (age $3 \mathrm{yr}$ ). The mean and 95\% credibility interval for the weight (in grams), total length (in $\mathrm{cm}$ ) and standard length, (in $\mathrm{cm}$ ), were calculated using Bayesian statistics (Tab. II).

The samples for ecological studies were fixed in $10 \%$ buffered formalin. In the laboratory fish were examined for parasites following the protocol of MARCOGLIESE (2007). All parasites were studied according to methods of Pritchard \& KRUSE (1982). The parasites studied were deposited in the helminthological (MLP) and in the crustacean collection of Museo de La Plata, Argentina (MLP-Cr).

Ecological terminology follows Bush et al. (1997). According with MAGURRAN (1998) were calculated at the infracommunity level the species richness (S), number of parasites, Shannon-Wiener diversity index $(\mathrm{H})$, Pielou evenness index (E), the Berger Parker dominance index (D), the dominant specie, the percent of uninfected fishes, and the percent of parasited fishes, and to the community component the prevalence of infection, the number of parasites $(\mathrm{Ncc})$, the species richness $(\mathrm{Scc})$, the ShannonWiener diversity index (Hcc), Pielou evenness index (E), and complement of Simpson dominance index (Simpson).
The Shannon-Wiener index of diversity was calculated using base 10 logarithms. All parasites species were considered for the calculation of the community index.

The Shannon-Wiener diversity index, Pielou evenness index and complement of Simpson dominance index were calculated with the codes proposed by GoLICHER et al. (2006). It was calculated the DIC (deviance information criterion) for both codes (LogNorm and Gamma) being the latter smaller (233,32 vs 263,77 in S1, 228,61 vs 246,69 in S2) and used for the component community calculations.

WinBUGS was used to generate 100,000 samples from the posterior distributions for each of the analyses after discarding the initial 10,000 samples as a 'burn in'. The mean and the 2,5th and 97,5th percentiles of the distribution of each parameters was calculated with the statistic programs Epidat 4.0 and WinBUGS software (http://www.sergas.es) and (http://www2.mrc-bsu.cam. ac.uk/bugs/winbugs).This interval was used to represent a 95\% Bayesian credible interval. The first year sampled was used as "prior" of the second year. A significance level $(\alpha)$ of $5 \%$ or less was considered significant $(\mathrm{P}<=0.05)$.

\section{RESULTS}

Fish studied harbored a total of 15 species of parasites (Tab. III), of which five were digeneans [Dicrogaster fastigata Thatcher \& Sparks, 1958, Hymenocotta manteri Overstreet, 1969, Ascocotyle (Phagicola) longa Ransom, 1920, Phyllodistomum mugilis Knoff \& Amato, 1992 and Metacercariae Hemiuridae gen. sp.]; three species were monogeneans (Ligophorus sp., Macrocotyle macracantha Koratha, 1955 and Microcotyle pseudomugilis Hargis, 1957); four species were copepods (Ergasilus versicolor Wilson, 1911, Ergasilus atafonensis Amado \& Rocha, 1997, Parabrachiella sp. 1, Parabrachiella sp. 2); one species of acanthocephalan (Floridosentis mugilis Machado, 1951); and, one species of hirudinean (Myzobdella uruguayensis Mañe Garzon \& Montero, 1977).

Tab. I. Number of juvenile lebranche mullet in each size from both sites, Samborombón bay, Argentina (A.R., Ajó River; S.R.C., Salado River relief Channel).

\begin{tabular}{|c|c|c|c|c|c|c|}
\hline & \multicolumn{2}{|c|}{ S.R.C. } & \multicolumn{3}{|c|}{ A.R. } & \multirow[t]{2}{*}{ Total } \\
\hline Sample year & Size 1 & Size 2 & Size 1 & Size 2 & Size 3 & \\
\hline 2009 & 59 & 6 & 93 & 3 & 0 & 161 \\
\hline 2010 & 60 & 5 & 17 & 29 & 6 & 117 \\
\hline Total & 119 & 11 & 110 & 35 & 6 & 278 \\
\hline
\end{tabular}

Tab. II. Weight (in gr.), Total and Standard Length (in mm) of lebranche mullets (A.R., Ajó River; ds, standard deviation; S1, size 1; S2, size 2; S3,size 3; S.R.C., Salado River relief Channel).

\begin{tabular}{cccccccc}
\hline & \multicolumn{3}{c}{$\begin{array}{c}\text { Weight } \\
\text { Mean and range }\end{array}$} & ds & $\begin{array}{c}\text { Total length } \\
\text { Mean and range }\end{array}$ & ds & \multicolumn{2}{c}{$\begin{array}{c}\text { Standard length } \\
\text { Mean and range }\end{array}$} \\
\hline S1 & AR & $7,93(5,95-9,89)$ & 1 & $8,89(6,86-10,87)$ & 1,01 & $7,4(5,65-9,16)$ & 0,89 \\
& SRC & $6,1(4,66-7,54)$ & 0,73 & $6,6(5,68-7,52)$ & 0,47 & $4,99(4,2-5,79)$ & 0,4 \\
& & & & & & & \\
S2 & AR & $170,9(170,7-171,1)$ & 0,09 & $25,02(24,04-25,69)$ & 0,34 & $21,05(20,37-21,72)$ & 0,34 \\
& SRC & $58,14(57,11-59,15)$ & 0,52 & $18,79(17,33-20,23)$ & 0,74 & $15,62(14,28-16,94)$ & 0,68 \\
& & & & & & & \\
S3 & AR & $308,4(231,3-381,8)$ & 39,05 & $32,83(30,76-34,88)$ & 1,05 & $27,15(25,91-28,39)$ & 0,63 \\
\hline
\end{tabular}


Tab. III. Population parameters and microhabitat of parasites in lebranche mullet size from both sites, Samborombón bay, Argentina: Part A, Salado River Relief Channel; Part B, Ajó River [A.(P.) longa, Ascocotyle (Phagicola) longa; c, coelom; D. fastigata, Dicrogaster fastigata; E. atafonensis, Ergasilus atafonensis; E. versicolor, Ergasilus versicolor; f, fins; F. mugilis, Floridosentis mugilis; g, gill; H. manteri, Hymenocotta manteri; in, intestine; m, mesentery; MA, median abundance; MI, median intensity; M. macracantha, Metamicrocotyle macracantha; M. pseudomugilis, Microcotyle pseudomugilis; msc, muscle; M. uruguayensis, Myzobdella uruguayensis; n, nostrils; P, prevalence; P. mugilis, Phyllodistomum mugilis].

Part A - Salado River Relief Channel

\begin{tabular}{|c|c|c|c|c|c|c|c|}
\hline & \multirow[b]{2}{*}{ Microhabitat } & \multicolumn{3}{|c|}{ Size 1} & \multicolumn{3}{|c|}{ Size 2} \\
\hline & & $\mathrm{P}$ & MI & MA & $\mathrm{P}$ & MI & MA \\
\hline \multicolumn{8}{|l|}{ DIGENEA } \\
\hline D. fastigata & in & $50(40-59)$ & $12(6-18)$ & $0.53(0-1.1)$ & $68(50-85)$ & $149(9-289)$ & $44(0.7-88)$ \\
\hline H. manteri & in & $21(14-29)$ & $42(19-65)$ & $31.6(11.7-51.5)$ & $60(41-78)$ & $24(9-39)$ & $7.7(1.3-14)$ \\
\hline A. (P.) longa & $\mathrm{m}, \mathrm{msc}$. & $14(8-20)$ & $13(3-23)$ & $0.5(0-1)$ & $64(46-82)$ & $19(1-42)$ & $12.5(0-26.6)$ \\
\hline P. mugilis & $\mathrm{c}$ & ----- & ----- & ----- & ----- & ----- & ----- \\
\hline Hemiuridae gen. sp. & $\mathrm{c}$ & $3(1-10)$ & 2 & $0.04(0-0.11)$ & ----- & ----- & ----- \\
\hline \multicolumn{8}{|l|}{ MONOGENEA } \\
\hline Ligophorus sp. & $\mathrm{g}$ & $46(36-55)$ & $9(5-12)$ & $4.5(2.5-6.5)$ & $60(41-78)$ & $12(4-20)$ & $7(2-11.8)$ \\
\hline M. macracantha & $\mathrm{g}$ & ----- & ----- & ----- & ----- & ----- & ----- \\
\hline M. pseudomugilis. & $\mathrm{g}$ & $5(1.1-8.5)$ & 1 & $0.03(0.01-0.06)$ & ----- & ----- & ----- \\
\hline \multicolumn{8}{|l|}{ COPEPODA } \\
\hline E. versicolor & $\mathrm{g}$ & ----- & ----- & ----- & ----- & ----- & ----- \\
\hline E. atafonensis & $\mathrm{g}$ & $4(0.7-7.2)$ & $1.5(1-2)$ & $0.03(0-0.06)$ & $20(6-36)$ & $2(1-14)$ & $0.36(0-0.92)$ \\
\hline Parabrachiella sp. 1 & $\mathrm{n}$ & $5(1-11)$ & $2(1-18)$ & $0.07(0-0.17)$ & $12(2-24)$ & $1.8(1-3)$ & $0.69(0.1-1.29)$ \\
\hline Parabrachiella sp. 2 & $\mathrm{f}$ & ----- & ----- & ----- & ----- & ----- & ----- \\
\hline \multicolumn{8}{|l|}{ ACANTOCEPHALA } \\
\hline F. mugilis & in & $6(2-10)$ & $1.7(1-4)$ & $0.05(0-0.1)$ & $32(15-50)$ & 1 & $0.63(0.2-1.08)$ \\
\hline \multicolumn{8}{|l|}{ HIRUDINEA } \\
\hline M. uruguayensis & $\mathrm{g}$ & $23(4-45)$ & 1 & $0.2(0-0.46)$ & ----- & ----- & ----- \\
\hline
\end{tabular}

Part B - Ajó River

\begin{tabular}{|c|c|c|c|c|c|c|c|c|c|}
\hline & \multicolumn{3}{|c|}{ Size 1} & \multicolumn{3}{|c|}{ Size 2} & \multicolumn{3}{|c|}{ Size 3} \\
\hline & $\mathrm{P}$ & MI & MA & $\mathrm{P}$ & MI & MA & $\mathrm{P}$ & MI & MA \\
\hline \multicolumn{10}{|l|}{ DIGENEA } \\
\hline D. fastigata & $71(62-79)$ & $80(58-102)$ & $57.7(40.6-74.8)$ & $44(28-61)$ & $91(6-289)$ & $76.4(5-147.8)$ & $63(32-92)$ & $205(1-715)$ & $137(0-395.89)$ \\
\hline H. manteri & $23(16-31)$ & $2(1-5)$ & $0.1(0-0.18)$ & $18(7-30)$ & $2(1-7)$ & $0.4(0-1)$ & ----- & ----- & ----- \\
\hline A. (P.) longa & $30(22-39)$ & $12(6-18)$ & $0.9(0.1-2)$ & $46(31-62)$ & $9(2-16)$ & $6(1-11)$ & $25(1-53)$ & 4 & $0.7(0-2.7)$ \\
\hline P. mugilis & $11(0-24)$ & 1 & $0.07(0-0.18)$ & ----- & ----- & ----- & ----- & ----- & ----- \\
\hline $\begin{array}{l}\text { Hemiuridae gen. sp. } \\
\text { MONOGENEA }\end{array}$ & ---- & ----- & ---- & ----- & ----- & ----- & ----- & ----- & ----- \\
\hline Ligophorus sp. & $54(44-63)$ & $5(3-6)$ & $1.6(0.9-2.2)$ & $28(14-42)$ & $1(1-3)$ & $4.8(0.1-9.5)$ & $25(1-53)$ & 16 & $2.7(0-10.8)$ \\
\hline M. macracantha & $6(2-11)$ & 1 & $0.05(0.01-0.09)$ & $23(11-36)$ & $1(1-2)$ & $0.08(0.05-0.3)$ & ----- & ----- & ----- \\
\hline $\begin{array}{l}\text { M.pseudomugilis. } \\
\text { COPEPODA }\end{array}$ & $6(2-10)$ & $2(1-4)$ & $0.01(0-0.02)$ & ----- & ---- & ---- & ----- & ----- & ----- \\
\hline E. versicolor & $14(8-21)$ & $1.5(1-2)$ & $0.15(0.05-0.25)$ & $8(1-16)$ & $3(0-9)$ & $0.34(0-1.03)$ & ----- & ----- & ----- \\
\hline E. atafonensis & ----- & ----- & ----- & ----- & ----- & ----- & ----- & ----- & ----- \\
\hline Parabrachiella sp. 1 & $46(37-56)$ & $2.5(2-3)$ & $0.93(0.66-1.2)$ & $20(9-33)$ & $2.3(0-4.35)$ & $0.33(0-0.65)$ & ----- & & $0.02(0-0.03)$ \\
\hline Parabrachiella sp. 2 & $8(3-13)$ & $1.3(1-2)$ & $0.06(0-0.12)$ & $10(2-20)$ & $1(1-4)$ & $0.14(0-0.3)$ & ----- & ----- & ----- \\
\hline ACANTOCEPHALA & & & & & & & & & \\
\hline $\begin{array}{l}\text { F. mugilis } \\
\text { HIRUDINEA }\end{array}$ & $21(5-39)$ & 1 & $0.29(0-0.64)$ & $56(41-72)$ & 1 & $0.31(0-0.61)$ & $75(47-99)$ & $4(1-10)$ & $3.5(0-7.93)$ \\
\hline M. uruguayensis & ----- & ----- & ----- & ----- & ----- & ----- & ----- & ----- & ----- \\
\hline
\end{tabular}

Some parasites were found only in one location (Hemiuridae gen. sp., E. atafonensis and M. uruguayensis in S.R.C. and P. mugilis, M. macracantha, E. versicolor and Parabrachiella sp. 2 in A.R.), those parasites were not used for the population comparisons.

\section{Population parameters}

Prevalence. When analyzed, the size 1 (S1) mullets from both sites, evidenced a significant higher prevalence of D. fastigata, A (P.) longa and Parabrachiella sp. 1 in A.R. For size 2 (S2) mullets, the digenean H. manteri evidenced a significant higher prevalence in the S.R.C. samples. In A.R. samples the prevalence of D. fastigata, and Ligophorus sp. were significant bigger in the size 1 (S1) compared with S2 fishes, but within size 3 (S3) fishes prevalence was not statistically significant different to both sizes (S1 and S2). The copepod Parabrachiella sp. 1 was more prevalent in $\mathrm{S} 1$ fish, M. macracantha was more prevalent in $\mathrm{S} 2$ fish and $F$. mugilis was more prevalent in $\mathrm{S} 2$ and $\mathrm{S} 3$ than in S1 fish at the A. R. sample site. In the Salado River relief Channel (S.R.C.) the prevalence of H. manteri, A. (P.) longa and F. mugilis were significant higher in S2 than in S1 fish.

Mean intensity. When analyzed the S1 from both sites $D$. fastigata evidenced significant higher mean intensity of parasite species observed in the A.R. samples. In $\mathrm{S} 2$ class juvenile mullets from S.R.C. the mean intensity of both $H$. manteri and Ligophorus sp. were significantly greater than observed in A.R. samples. In A.R. the mean 
intensity of Ligophorus sp. was significant higher in S3 fishes compared with $\mathrm{S} 1$ and $\mathrm{S} 2$ size classes, while intensity within $\mathrm{S} 1$ and $\mathrm{S} 2$ classes were not statistically significant different. The mean intensity of Ascocotyle (P.) longa was not statistically significant different in $\mathrm{S} 1$ and $\mathrm{S} 2$ size classes, but significant lower for $\mathrm{S} 3$ than $\mathrm{S} 1$ size class. In the S.R.C. there is no difference observed between sizes.

Mean abundance. When analyzed the S1 fishes from both sites $D$. fastigata and Parabrachiella sp. 1 were significant greater mean abundance in the A.R. samples. In the S.R.C. samples, H. manteri and Ligophorus sp. evidenced significant higher mean abundance. The comparison of the $\mathrm{S} 2$ size classes of the two sample sites, indicated a significant higher mean abundance of $H$. manteri was observed in S.R.C. than in the A. R. In A.R. samples, only Parabrachiella sp. 1 was significant more abundant in the $\mathrm{S} 1$ size fish than o S2. In S.R.C. samples F. mugilis was significant more abundant in S2 size fish than in S1 fish.

Infracommunity level. The Table IV reflects the community indexes for both sites, S.R.C and A.R. The most dominant parasite species observed in all the sizes of juvenile mullet samples at both sites was $D$. fastigata. The $\mathrm{S}$ and the Shannon-Wiener diversity index were similar in both sites in all the sizes. The number of parasites sowed no meaning differences inside the $\mathrm{S} 1$ of mullets from both sizes. In A.R. the S1 have more parasites than the others sizes.

Evenness was bigger and significant in S1 and S2 from S.R.C than the A.R. In this latter site, the evenness of $\mathrm{S} 1$ was bigger and significant than $\mathrm{S} 2$, and this last two were not significant different than S3. The S1 from S.R.C. have a bigger and significant percent's of uninfected fishes than same sizes in A.R.

In A.R. (Tab. V) the fishes of S1 and S2 were infected with three and the S3 only with two parasite species. In S.R.C, in contrast with A.R., some fishes had 6-7 parasite species. In this site the fishes were parasitized more frequently with two parasite species.

The correlation (Tab. VI) between LT of mullets and $S$ was negative in the $S 1$ from A.R. and positive in S.R.C. The correlation with the $\mathrm{N}$ was positive in $\mathrm{S} 1$ and $\mathrm{S} 2$ from A.R. and S1 from the S.R.C. The correlation with the Shannon-Wiener diversity index was negative in $\mathrm{S} 1$ and $\mathrm{S} 2$ from A.R. but both sizes in the S.R.C were positive.

Component community. The Berger Parker dominance index is plotted in Figs 1-3. In the S1 from R.A. the species with significant higher dominance after D. fastigata were Ligophorus sp., A. (P.) longa and Parabrachiella sp. In the S1 class samples of S.R.C. the dominance of D. fastigata wasn't so overwhelmed as in the A. R. and secondarily dominant species were Ligophorus sp., H. manteri and $A$. (P.) longa. For $\mathrm{S} 2$ class fish sampled in A.R. found $A$. (P.) longa to be the second most dominant species after D. fastigata. In the S2 of S.R.C. the most dominant species after $D$. fastigata were $A$. (P.) longa, H. manteri and Ligophorus sp. The $\mathrm{S} 3$ size class samples of A.R. the most dominant species after D. fastigata was
F. mugilis.

The parasite samples of $\mathrm{S} 1$ size fish of S.R.C. were compared with S2 size there and found to evidence significantly great species richness ( $\mathrm{Scc}$ ), Shannon-Wiener diversity index (Shannon) and complementary of Simpson equitability index (Simpson). In the A.R. the S1 size class was compared with S2 and S3 in the same site and found the S1 fish had the highest values of species richness, number of parasites, and Shannon and Simpson indices. The $\mathrm{S} 2$ had a significant great species richness of parasites than S3 fish sampled in the same site.

When comparing parasite loads between the same fish sizes at the two sites, found the S1 class samples of S.R.C. had a significant higher prevalence (Pcc), ShannonWiener and Simpson index, but evidenced significant lower counts of parasites and significant lower species richness than the S1 from A.R. The S2 sample class of S.R.C. indicated greater Shannon and Simpson indices than S2 of A.R. The prevalence of parasites in both sites was not significant different than in S2 samples, but the species richness was greater for parasites in S2 samples of A.R.

\section{DISCUSSION}

The high number of parasite species found in comparison with past studies may be explained by the fact that here were analyzed juvenile mullets that could be more susceptible to infection by parasites, or alternately, there may have been other factors such as behavior differences, lower immunological competence, or environmental changes (KHAN, 2012).

We agree with Alarcos \& Etchegoin (2010) who stated $M$. liza as definitive host because the parasites here found were monoxenous cycles (Ligophorus sp., $M$. macracantha, M. pseudomugilis, Parabrachiella sp. 1, Parabrachiella sp. 2, E. versicolor, E. atafonensis and M. uruguayensis) or adults of heteroxenous cycles $(D$. fastigata, H. manteri, P. mugilis, F. mugilis) demonstrating $M$. liza as a definitive host even when they are juveniles.

There was evidence that reported differences between the environments of the two sites (SCHENONE et al., 2007, 2008) studied may affect and/or alter the parasite fauna present in each. SCHENONE et al. (2007, 2008) clustered the sites in the north end of the Bay based in similar $\mathrm{pH}$ values, dissolved oxygen, high concentrations of nutrients, phosphorus and nitrogen and also containing the same kinds of contaminants, such as lead, zinc, copper and arsenic. In the south of the bay, the group of streams and channels present share similar values of $\mathrm{pH}$, concentration of oxygen and conductivity due to being near the ocean and lack many of the contaminants and agricultural sourced nutrients as a factor of being far away from the discharge of Parana and Uruguay Rivers into the La Plata River. In A. R. the saline waters allow the development of parasites normally found in adults mullets (P. mugilis, M. macracantha, E. versicolor) of Argentina (Alarcos \& ETCHEGOIN, 2010) and Brazil (KNOFF \& AMATo, 1992; 
Tab. IV. Community parameters of each lebranche mullet size in both environments, Samborombón bay, Argentina (A.R., Ajó River; Evenness, Pielou evenness index; Ncc, number of parasite; Pcc, prevalence of parasitic infection; S, species richness; S1, size 1; S2, size 2; S3, size 3; Scc, species richness of the community component; Shannon, Shannon-Wiener diversity index; Simpson, complement of Simpson dominance index; S.R.C., Salado River relief Channel).

\begin{tabular}{|c|c|c|c|c|c|c|}
\hline & & \multicolumn{2}{|c|}{ S.R.C. } & \multicolumn{3}{|c|}{ A.R } \\
\hline & & $\mathrm{S} 1$ & $\mathrm{~S} 2$ & $\mathrm{~S} 1$ & $\mathrm{~S} 2$ & S3 \\
\hline \multirow{8}{*}{ Infracomunity } & $\mathrm{N}^{\mathrm{o}}$ Fishes & 119 & 11 & 110 & 32 & 6 \\
\hline & $\mathrm{S}$ & $2.26(1.99-2.53)$ & $3.57(2.22-4.93)$ & $2.72(2.48-2.97)$ & $2.8(2.46-3.13)$ & $2.2(1.49-2.91)$ \\
\hline & $\mathrm{N}^{\mathrm{o}}$ Parasites & $32.41(17.20-47.62)$ & $78.56(1-169.87)$ & $75.8(57-95)$ & $29.63(5.27-53.99)$ & $32.35(8-57)$ \\
\hline & Shannon & $0,31(0,24-0,37)$ & $0,59(0,19-0,98)$ & $0,35(0,28-0,43)$ & $0,26(0,16-0,36)$ & $0,32(0-0,47)$ \\
\hline & Evenness & $0,64(0,58-0,71)$ & $0,67(0,5-0,85)$ & $0,45(0,39-0,51)$ & $0,27(0,19-0,36)$ & $0,65(0,2-1,1)$ \\
\hline & Berger parker & $0,74(0,73-0,75)$ & $0,82(0,81-0,83)$ & $0,87(0,86-0,88)$ & $0,93(0,93-0,94)$ & $0,95(0,94-0,96)$ \\
\hline & Dominant specie & D. fastigata & D. fastigata & D. fastigata & D. fastigata & D. fastigata \\
\hline & Uniffected fish & $26(19-35)$ & $17(4-45)$ & $10(5-16)$ & $9(1-34)$ & $22(1-53)$ \\
\hline \multirow{5}{*}{ Community Component } & Pcc & $74(65-81)$ & $83(55-96)$ & $90(84-95)$ & $91(66-99)$ & $78(47-99)$ \\
\hline & $\mathrm{Ncc}$ & 5448 & 3289 & 7099 & 29578 & 863 \\
\hline & Scc & 10 & 6 & 11 & 10 & 4 \\
\hline & Shannon & $0.99(0.92-1.07)$ & $0.62(0.58-0.65)$ & $0.58(0.48-0.68)$ & $0.29(0.28-0.30)$ & $0.24(0.19-0.30)$ \\
\hline & Simpson & $2.29(2.19-2.41)$ & $1.39(1.36-1.43)$ & $1.34(1.21-1.27)$ & $1.14(1.13-1.15)$ & $1.1(1.07-1.14)$ \\
\hline
\end{tabular}

Tab. V. Number of parasite species in the lebranche mullet sizes from both sites, Samborombón bay, Argentina (A.R., Ajó River; S1, size 1; S2, size 2; S3, size 3; S.R.C., Salado River relief Channel).

\begin{tabular}{|c|c|c|c|c|}
\hline & & $\mathrm{S} 1$ & $\mathrm{~S} 2$ & S3 \\
\hline \multirow{5}{*}{ A. $R$} & 1 species & $18(11,6-26,10)$ & $8,7(2-19)$ & ----- \\
\hline & 2 species & $17,1(10,8-25,10)$ & $30,33(20,70-49,7)$ & $56(31,5-92)$ \\
\hline & 3 species & $32,37(24,8-42,6)$ & $23,8(14,3-41,3)$ & $22(1,3-52,7)$ \\
\hline & 4 species & $15,3(9,6-22,9)$ & $19,47(10,4-35,4)$ & ---- \\
\hline & 5 species & $7,23(2,9-12,5)$ & $8,7(2-19)$ & ----- \\
\hline \multirow{7}{*}{ S.R.C. } & 1 species & $23,6(17,3-32,5)$ & $11,03(0,6-34,1)$ & ----- \\
\hline & 2 species & $22,84(16,6-31,6)$ & $11,11(0,6-34,1)$ & ----- \\
\hline & 3 species & $12,56(7,5-19,3)$ & $22,22(8-54,8)$ & ----- \\
\hline & 4 species & $8,66(4,3-14,3)$ & $16,66(3,6-45)$ & ----- \\
\hline & 5 species & $3,14(0,6-6,5)$ & $11,03(0,6-34,1)$ & ----- \\
\hline & 6 species & $1,6(0-3,9)$ & $11,03(0,6-34,1)$ & ----- \\
\hline & 7 species & $1,6(0-3,9)$ & ----- & ----- \\
\hline
\end{tabular}

Tab. VI. Correlation index between total length and species richness (S), number of parasites (N) and Shannon-Wiener diversity index (A.R., Ajó River; S1, size 1; S2, size 2; S3, size 3; S.R.C., Salado River relief Channel).

\begin{tabular}{|c|c|c|c|}
\hline & & S.R.C. & A.R. \\
\hline \multirow{3}{*}{ Species Richness } & $\mathrm{S} 1$ & $0,54(0,48-0,61)$ & $-0,97((-0,95)-(-0,99))$ \\
\hline & $\mathrm{S} 2$ & $0,18((-0,4)-0,76)$ & $0,03((-0,14)-0,21)$ \\
\hline & $\mathrm{S} 3$ & ----- & $0,11((-0,7)-0,81)$ \\
\hline \multirow{3}{*}{ Number of Parasites } & $\mathrm{S} 1$ & $0,56(0,53-0,58)$ & $0,16(0,04-0,21)$ \\
\hline & $\mathrm{S} 2$ & $0,05((-0,01)-0,12)$ & $0,15(0,08-0,22)$ \\
\hline & $\mathrm{S} 3$ & ----- & $-0,07((-0,74)-0,67)$ \\
\hline \multirow{3}{*}{ Shannon-Wiener Diversity Index } & $\mathrm{S} 1$ & $0,17(0,05-0,29)$ & $-0,98((-0,99)-(-0,95))$ \\
\hline & $\mathrm{S} 2$ & $0,22(0,12-0,32)$ & $-0,63((-0,83)-(-0,44))$ \\
\hline & S3 & ----- & $-0,17((-0,84)-(0,65))$ \\
\hline
\end{tabular}

KnOFF et al., 1994, 1997). Also we found that in A.R sample sites some species, such as $A$. (P.) longa, D. fastigata, and Parabrachiella sp. 1 were more abundant than in S.R.C. samples.

In the S. R. C. sample site found H. manteri and
Ligophorus sp. were more abundant than observed in A.R. samples, perhaps as result of fresh water or physicalchemical environmental conditions.

The six individuals of $\mathrm{S} 3$ size class from A.R. in our sample were in poorly preserved condition. More fishes 


\section{Berger Parker Dominance in size 1}

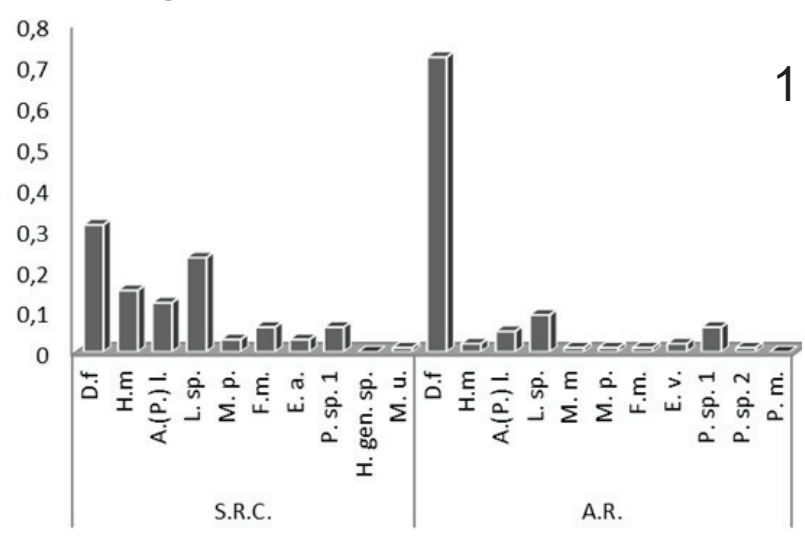

Berger Parker Dominance in size 2

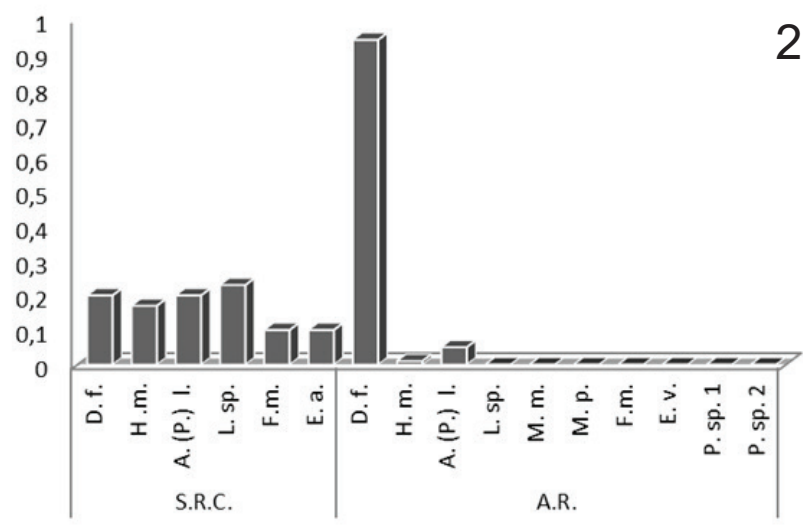

Berger Parker Dominance in size 3

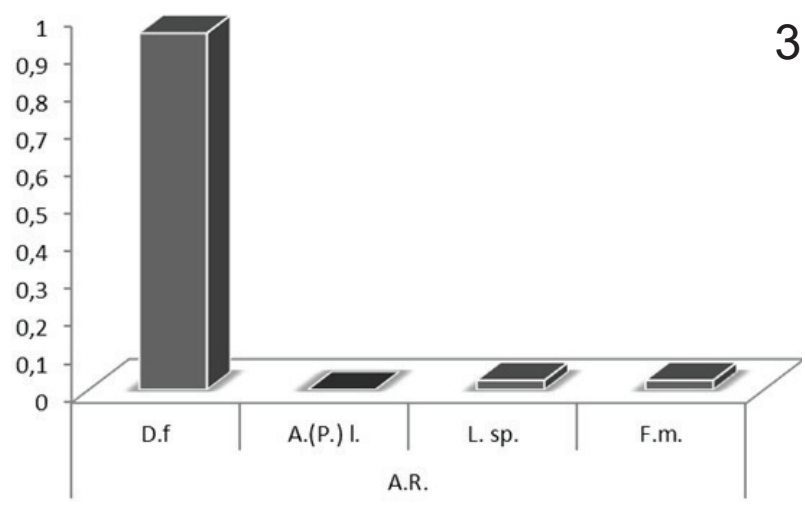

Figs 1-3. The Berger Parker dominance index: 1, in size 1; 2, in size 2; 3, in size 3 [A. (P.) 1., Ascocotyle (Phagicola) longa; D. f., Dicrogaster fastigata; E. a., Ergasilus atafonensis; E.v., Ergasilus versicolor; F. m., Floridosentis mugilis; H. m., Hymenocotta manteri; L. sp, Ligophorus sp.; M. m., Macrocotyle macracantha; H. gen. sp., Metacercariae Hemiuridae gen. sp.; M. p., Microcotyle pseudomugilis; M. u., Myzobdella uruguayensis; P. sp. 1, Parabrachiella sp. 1; P. sp. 2, Parabrachiella sp. 2; P. m., Phyllodistomum mugilis].

of this size must be examined to be positive of observed patterns being valid, but even with these preservation problems was observed a pattern of an increase of $F$. mugilis present as mullets parasitized got to be older/bigger. That pattern was also observed across the two sizes of mullets in S.R.C. samples.

The A.R. samples evidenced differences between juvenile fish size classes in the prevalence and abundances of some parasites (D. fastigata, Ligophorus sp. and Parabrachiella sp.) perhaps reflecting different use of the habitat, different habitats, or different susceptibility to the parasites. In the S.R.C. study area the habitat frequented by the young mullets appeared to be more homogenous, because there was not a great difference in the parasite species present across mullet age classes, and, only a moderate increase in the presence of $H$. manteri and $F$. mugilis observed in the S2 age class mullets.

A special analysis must be done to identify parasites of Ligophorus species. They are very small monogenans and determine them is complex because species only differ in characteristics of the vagina or penis. Thus, differences of Ligophorus species found within and between both sample sites (and fish sizes in each) may obscure different species identification, including some which could be new to science.

The increase in the prevalence and mean abundance of monogenean in the higher sizes could be explain by a grown of the fish or a bigger encounter of mullets facilitating the transmission of this parasites.

In Argentina the metacercariae of $A$. (P.) longa was not reported in adult mullets, but have been mentioned parasitizing juvenile mullets by CARNEVIA \& SPERANZA (2003) and LADO et al. (2013) from Uruguayan coast of La Plata River and MARCOTEGUI et al. (2009), MARTORELLi et al. (2012) and MonTES et al. (2013), in Argentinean waters. In this work we increased the distribution between different sizes of mullets analyzed by MARTORELLI et al. (2012). In both sites studied, the prevalence of $A(P)$ longa increased as the mullets parasitized got bigger, and the mean abundance and mean intensity remained similar within each size for the same site. The mullets from A.R. and the $\mathrm{S} 2$ from the S.R.C. had a greater prevalence of parasitism by $A$. (P.) longa because they seem to live in waters with a higher salt concentration (or marine influence). That environment is suitable for the development of $A$. (P.) longa or the intermediate host (Helobia australis d'Orbigny, 1835). The absence of this parasite in the mullets analyzed by Alarcos \& Etchegoin (2010) could be explained by the type of life cycle of the parasite, more vulnerability of the juveniles, sampling errors or environmental condition in Mar Chiquita lagoon.

The great numerical dominance played by $D$. fastigata reduced values of community indexes at the S. R. C. study site and more in A.R. sample even when species richness was greater than in S.R.C. samples. The digenean may be filling the habitat for other intestinal parasites being a strong competitor and perhaps displacing other species. Dicrogaster fastigata may be used as sentinel for controlling ambient changes. The high presence in A.R of this parasite agrees with LADO et al. (2013) who found a high prevalence of this parasite in mullets from saline 
waters of Uruguay. In neither site of this study did we find the snail species that serves as host of the immature stages of this parasite.

New works about juvenile (and mainly adults) of M. liza in the Samborombón bay as in other localities of Argentina, help provide elucidation of how the different life histories of the various parasites are be important in understanding the risk of finding zoonotic metacercariae of $A$. (P.) longa in local mullet populations. They also may help find ways of using mullet parasites in other promising fields, such as functioning as indicators of biodiversity, environmental contamination, and expanded use of this fish as food and as an economic resource for local export.

Acknowledgements. We are grateful to Agustin Solari for their help in providing fishes from Samborombón bay. Miguel Risso for his support and knowledge in Bayesian statistics. We express gratitude to Philip Whitford, Biology Department, Capital University, Columbus, Ohio, USA for useful advice in improving the manuscript. This work was partially funded by a research grant from the Agencia Nacional de Promoción Científica y Técnica (PICT 34412/05 and PID 0257) to S. R. Martorelli.

\section{REFERENCES}

Abdallah, V. D.; Azevedo, R. K. \& LuQue, J. L. 2009. Four new species of Ligophorus (Monogenea: Dactylogyridae) parasitic on Mugil liza (Actinopterygii: Mugilidae) from Guandu River, Southeastern Brazil. Journal of Parasitology 95:855-864.

Alarcos, A. J. \& Etchegoin, J. A. 2010. Parasite assemblages of estuarine-dependent marine fishes from Mar Chiquita coastal lagoon (Buenos Aires Province, Argentina). Parasitology Research 107(5):1083-1091.

Amado, M. A. P. \& Rocha, C. E. F. 1995. Tres novas espécies de copepodes parasitas do gênero Ergasilus (Poecilostomatoida, Ergasilidae) coletadas em filamentos branquiais de peixes mugilideos do Brasil. Nauplius 3:33-48.

Aparecida de Oliveira, S.; Hernandez Blazquez, F. J.; Antunes, S. A. \& Mendes, M. A. A. 2007. Metacercarias de Ascocotyle (Phagicola) longa Ramsom, 1920 (Digenea: Heterophyidae), em Mugil platanus, no estuario de Cananeia, SP, Brasil. Ciência Rural 37(4):1056-1059.

Bush, A. O.; Lafferty, K. D.; Lutz, J. L. \& Shostak, A. W. 1997. Parasitology meets ecology on its own terms: Margolis et al. revisited. Journal of Parasitology 83:575-583.

Carnevia, D. \& Speranza, G. 2003. Seasonal variations in parasites found in mullet (Mugil platanus Gunther, 1880) juveniles captured on the Uruguayan coast of the River Plate. Bulletin European Association of Fish Pathologists 23(5):245-249.

Chiefri, P. P. 1990. Human parasitism by Phagicola longa (Trematoda: Heterophyidae) in Cananeia, São Paulo State, Brazil. Revista do Instituto de Medicina Tropical 32(4):285-288

ChiefFi, P. P.; Gorla, M. C. O.; Torres, D. M. A. G. V.; Dias, R. M. D. S.; Mangini, A. C. S.; Monteiro, A. V. \& Woiciechovski, E. 1992. Human infection by Phagicola sp. (Trematoda, Heterophydae) in the municipality of Registro, São Paulo State, Brazil. Journal of Tropical Medicine and Hygiene 95:346-348.

Failla Siquier, G. \& Ostrowski de Nuñez, M. 2009. Ligophorus uruguayense sp. nov. (Monogenea, Ancyrocephalidae), a gill parasite from Mugil Platanus (Mugilidformes, Mugilidae) in Uruguay. Acta Parasitologica 54(2):95-102.

Fernandez Cirelli, A.; Du Mortier, C. \& Volpedo, A. V. 2006. Influencia de las Actividades Agropecuarias en los Procesos de eutrofización en la Cuenca Baja del Río Salado (Provincia de Buenos Aires, Argentina). In: Tundisi, G.; Tundisi, T. M. \& Galli, C. S. eds. Eutrophication in South America: causes, consequences and technologies for management and control. São Carlos, Instituto Nacional de Ecologia de São Carlos, p. 17-34.
Fernandes, B. M. M. \& Cohen, S. C. 2006. A new species of Intromugil Overstreet \& Curran, 2005 (Digenea, Haploporidae) from the Brazilian marine fish Mugil liza Valenciennes (Perciformes, Mugilidae). Zootaxa 1328:63-68.

Framiñan, M. B. \& Brown, O. B. 1996. Study of the Rio de la Plata turbity front, Part I: Spatial and temporal distribution. Continental Shelf Research 16(10):1259-1282.

Godinho, H. M.; Serralheiro, P. C. Da S. \& Scorvo Filho, J. D. 1988. Revisão e discussão de trabalhos sobre as espécies do gênero Mugil (Teleostei, Perciformes, Mugilidae) da costa brasileira (Lat. $\left.3^{\circ} \mathrm{S}-33^{\circ} \mathrm{S}\right)$. Boletim do Instituto de Pesca 15:67-80.

Golicher, D. J.; O’Hara, R. B.; Ruiz-Montoya, L. \& Cayuela, L. 2006. Lifting a veil on diversity: a bayesian approach to fitting relative-abundance models. Ecological Applications 16(1):202-212.

Gonzalez Castro, M.; Macchi, G. J. \& Cousseaur, M. B. 2011. Studies on reproduction of the mullet Mugil platanus Günter, 1880 (Actinopterygii, Mugilidae) from the Mar Chiquita coastal lagoon, Argentina: Similarities and differences with related species. Italian Journal of Zoology 78(3):343-353.

KNOFF, M. \& AмAтo, J. F. R. 1992. Nova espécie do gênero Phyllodistomum Braun, 1899 (Gorgoderidae, Gorgoderinae) parasita de tainha, Mugil platanus Gunther, 1880 da costa do estado do Rio de Janeiro, Brasil. Revista Brasilera de Biologia 52(1):51-56.

Knoff, M. \& Boeger, W. A. 1994. Expanded description of the female of Lernaeeniscus longiventris Wilson, 1917 (Copepoda, Siphonostomatoida, Pennellidae) based on specimens from Mugil platanus Gunter, 1880 (Perciformes, Mugilidae) of the state of Rio de Janeiro, Brazil. Memórias do Instituto Oswaldo Cruz 89(3):313-317.

Knoff, M.; Luque, J. L. \& Amato, J. F. R. 1997. Community ecology of the metazoan parasites of grey mullets, Mugil platanus (Osteichthyes: Mugilidae) from the litoral of the state of Rio de Janeiro, Brazil. Revista Brasilera de Biologia 57(3):441-454.

KnOFF, M.; LuQue, J. L. \& TAKemoto, R. M. 1994. Parasitic copepods on Mugil platanus Gunther (Osteichtyes, Mugilidae) from the coast of the state of Rio de Janeiro, Brazil. Revista Brasilera de Parasitologia Veterinária 3:45-56.

KHAN, R. A. 2012. Host-parasite interactions in some fish species. Journal of Parasitology Research 2012 ID237280. 7p.

Lado, P.; Carnevia, D.; Perretta, A. \& Castro, O. 2013. Helobia conexa (Mollusca, Cochiliopidae) y Mugil platanus (Osteichthyes, Mugilidae), hospedador intermediario y definitivo de Dicrogaster fastigatus (Trematoda, Haploporidae) en Uruguay. Revista Argentina de Parasitología 2(1):16-21.

Magurran, A. E. 1988. Ecological diversity and its measurements. Princeton, Princeton University Press. 179p.

MARCOGLIESE, J. 2007. Ecological monitoring and assessment network: (EMAN) Protocols for measuring biodiversity: Parasites of fishes in fresh water: Environment Canada, St. Lawrence Centre, Montreal, Quebec, Canada. Available at $<\mathrm{http}$ ://www.eman-rese. $\mathrm{ca} /$ eman/ecotools/protocols/freshwater/parasites/parasites_fresh_e. pdf $>$. Accessed on 25 June 2011.

Marcotegui, P.; Alda, M. del P.; Cardillo, F.; Draghi, R. \& Martorelli, S. 2009. Digeneos parásitos en juveniles de Mugil platanus (Osteichthyes Mugilidae) de la Bahía Samborombón. V Congreso Argentino de Parasitología. Acta Bioquímica Clínica Latinoamericana (Supl. 1):1-131.

Marcotegui, P. S. \& Martorelli, S. R. 2009. Ligophorus saladensis n. sp. (Monogenea: Ancyrocephalidae) from Mugil platanus Gunther in Samborombón Bay, Argentina. Systematic Parasitology 74:41-47.

Martinez Okumura, M. P.; Perez, A. C. A. \& Espindola Filho, A. 1999. Principais zoonoses parasitárias transmitidas por pescado - revisão. (Main parasitic zoonosis transmitted by fish-a review). Revista de Educação Continuada do CRMV-SP 2(2):66-80.

Martorelli, S. R.; Lino, A.; Marcotegui, P.; Montes, M. M.; Alda, P. \& PANEI, C. J. 2012. Morphological and molecular identification of the fish-borne metacercaria of Ascocotyle (Phagicola) longa Ransom, 1920 in Mugil liza from Argentina. Veterinary Parasitology 190:599-603.

Montes, M. M.; Marcotegui, P. S. \& Martorelli, S. R. 2013. Digeneos parásitos de juveniles de Mugil liza (Pisces: Mugilidae) en la Bahía 
de Samborombón, Argentina, con el reporte de metacercarias zoonóticas de Ascocotyle (Phagicola) longa. Revista Argentina de Parasitología 1:97-124.

OIA. 2007. Bahia de Samborombón Stripped Mullet Fishery Assessment Tree Including an Ecological Risk Assessment in Principles 1 and 2. Available at $<\mathrm{http}$ ://www.oia.com.ar/Noticias/ ATree-SMF-TA-v2.2.pdf > . Accessed on 18 February 2012.

Pritchard, M. H. \& Kruse, G. O. W. 1982. The collection and preservation of animal parasites. Lincoln, University of Nebraska Press. 141p.

Ramsar Convention Bureau. 2015. Bahia de Samborombon. Available at: <http://www.ramsar.org/bah\%C3\%ADa-desamboromb\%C3\%B3n>. Accessed on 20 September 2015.

Ranzani-Paiva, M. J. \& Silva-Souza, A. T. 2004. Co-infestation of gills by different parasite groups in the mullet, Mugil platanus Günther, 1880 (Osteichthyes, Mugilidae): effects on relative condition factor. Brazilian Journal of Biology 64(3B):677-682.

Schenone, N.; Volpedo, A. V. \& Cirelli, A. F. 2007. Trace metal contents in water and sediments in Samborombón Bay wetland, Argentina. Wetlands Ecology Manage 15:303-310.
2008. Estado trofico y variación estacional de nutrientes en los ríos y canales del humedal mixo-halino de Bahia Samborombón (Argentina). Limnetica 27(1):143-150.

Scholz, T. 1999. Taxonomic study of Ascocotyle (Phagicola) longa Ramsom, 1920 (Digenea: Heterophyidae) and related taxa. Systematic Parasitology 43:147-158.

Simões, S. B. E.; Santos Barbosa, H. \& Portes Santos, C. 2010. The life cycle of Ascocotyle (Phagicola) longa (Digenea: Heterophyidae), a causative agent of fish-borne trematosis. Acta Tropical 113:226-233.

Suriano, D. M.; Cuburu, M. L. \& Labriola, J. B. 2000. Floridosentis mugilis (Machado Filho, 1951) (Acanthocephala: Neoechinorhynchidae) from Mugil platanus Gunther, 1880 (Mugiliformes: Mugilidae) in San Clemente del Tuyu, Buenos Aires Province, Atlantic Coast, Argentina. Research and Revisions in Parasitology 60(3-4):107-112.

Urien, C. M. 1967. Los sedimentos modernos del Rio de la Plata Exterior, Argentina. Boletin Servicio de Hidrografia Naval 4(2):113-213. 